\title{
INDONESIA'S CONSTITUTIONAL IMMIGRATION POLICY: The Case of Rohingya Ethnic Group Refugees
}

\author{
Dian Wahyu Utami, Rahmat Saleh, Irin Oktafiani \\ Research Center for Population \\ Indonesian Institute of Sciences, Jakarta, Indonesia \\ Corresponding Author Email: dian.wahyu.dwu@gmail.com
}

\begin{abstract}
In this increasingly dynamic world, international migration especially international refugee and asylum seeker has become a hot issue in many countries, including Indonesia. For example, a communal conflict between Rakhine and Rohingya ethnic groups in Myanmar in 2012 calls the attention of the international community, especially in Southeast Asia regions. The socio-political situation forced the ethnic minority Rohingya to leave Myanmar to move (migrate) or seek asylum to the neighbouring countries, such as Indonesia. In Indonesia, Rohingya refugees are mostly surviving in the boats "Manusia Perahu" camp in Aceh since 2015. The influx of refugees such as Rohingya into Indonesia constitutes a new problem in constitutional and social terms. This paper aims to explain Indonesia's constitutional immigration policy and the public responses to asylum seekers taken from the case of Rohingya ethnic group in Indonesia. This study uses the literature review methods to explain the social problems and application of Indonesian regulations towards Rohingya refugees in the boats "Manusia Perahu" camp in Aceh. This study finds that a more explicit regulation is needed to regulate the entry of refugees, so that the locals will not be disturbed and still create security between countries.
\end{abstract}

Keywords: international refugee, asylum seekers, Rohingya, Manusia Perahu

\begin{abstract}
Di dunia yang semakin dinamis ini, migrasi internasional terutama pengungsi internasional dan pencari suaka telah menjadi isu panas di banyak negara, termasuk Indonesia. Misalnya, konflik komunal antara kelompok etnis Rakhine dan Rohingya di Myanmar pada tahun 2012 menarik perhatian masyarakat internasional, terutama di kawasan Asia Tenggara. Situasi sosial-politik memaksa etnis minoritas Rohingya meninggalkan Myanmar untuk pindah (bermigrasi) atau mencari suaka ke negara-negara tetangga, seperti Indonesia. Di Indonesia, pengungsi Rohingya sebagian besar bertahan di kamp "Manusia Perahu" di Aceh sejak tahun 2015. Masuknya pengungsi seperti Rohingya ke Indonesia merupakan masalah baru dalam hal konstitusional dan sosial. Makalah ini bertujuan untuk menjelaskan kebijakan imigrasi konstitusional Indonesia dan tanggapan publik terhadap para pencari suaka yang diambil dari kasus kelompok etnis Rohingya di Indonesia. Penelitian ini menggunakan metode tinjauan pustaka untuk menjelaskan masalah sosial dan penerapan peraturan Indonesia terhadap pengungsi Rohingya di kamp "Manusia Perahu' di Aceh. Studi ini menemukan bahwa peraturan yang lebih eksplisit diperlukan untuk mengatur masuknya pengungsi, sehingga penduduk setempat tidak akan terganggu dan masih menciptakan keamanan antar negara.
\end{abstract}

Kata Kunci: pengungsi internasional, pencari suaka, Rohingya, Manusia Perahu 


\section{INTRODUCTION}

According to the I95I Convention, refugees are people who are frightened as a result of rough treatment, mistreatment, which was caused by reasons of ethnicity, race, religion, nationality, specific social and political membership, who are outside of the country to request help in the country (UNHCR, 20I8). Refugees are a group of people who are forced to leave their homes due to fear or events that threaten the safety of their lives and their families (Pratama, 20I4). The United Nation's High Commissioners for Refugees (UNHCR) said that refugees would continue to increase over the next ten years due to the increasing trigger factors, such as climate change, population growth, urbanization, the threat of food and water scarcity, and competition for income generation (VOA, 20I2).

The increasing phenomenon of refugees and asylum seekers in the world often causes conflict in destination countries. The countries might respond in various ways to this issue, including rejecting the arrival of these refugees by prioritizing the social security of citizens or choosing to accept refugees as illegal immigrants and accommodate them (Nuswantoro, 2015). In Asia, the case of refugees that seized the attention was the Rohingya case that occurred in Myanmar. Rohingya ethnic or tribe is one of the tribes in Myanmar who lives in two northern cities of the state of Rakhine called Arakhan, the western city of Myanmar (Krustiyati, 20I2; Ula, 20I7). Physically, culturally, and linguistically, Rohingya ethnic is considered Asians, although some of them are Arabs, Persians, and Pathan (Tampubolon, Rahman, \& Bariah, 2013). Rohingya ethnic group of Myanmar has experienced a conflict that forced them to migrate and seek asylum.

Refugee conflict in Myanmar started with the dispute between ethnic Rohingya minorities and the Myanmar government (Wibisono, 20I6). According to Amnesty International, the Rohingya ethnic group has experienced human rights violations since 1978 , under the military army. This situation makes the Rohingya ethnic group not get the fundamental rights of citizens such as shelter, work, and welfare (Purwanto, 20I7). Also, the Myanmar government does not recognize Rohingyas as Myanmar citizens and thus expels them. The eviction is the beginning of violence and human rights violations experienced by the Rohingya ethnic group. They have experienced various forms of arbitrary extortion and taxation, deprivation of their property rights, and forced evictions by the government (Pratama, 20I4). Even for the needs of ethnic Rohingya marriages, they are required to pay huge sums of money (Ekeh, Chizom, \& Smith, 2007). All their public facilities are damaged, such as mosques, schools, and hospitals (Ula, 20I7). Rohingya Muslims are also forbidden to move from one region to another within Myanmar or to go abroad legally, like doing the Hajj. This is what makes them run away to other countries that they feel safer (Gill, 2015). Therefore, Rohingya of Myanmar is categorized as the most persecuted minority in the world (Riley, Varner, Ventevogel, \& Hasan, 2017), and one of the largest groups of stateless people (Kiragu, Rosi, \& Morris, 20II). This condition also has impacts on Myanmar's surrounding countries in South East Asia regions. It is because the spread of Rohingya refugees has passed the borders of other countries to seek asylum (Untoro, Idris, \& Hardiwinoto, 20I6). Their main countries of destination are Malaysia, Brunei, Thailand, Indonesia, as well as Australia, India, and Saudi Arabia (Azad \& Jasmin, 20I7).

Rohingya refugees come to Indonesia through several stages from 2012 until now, using small boats with minimal food so that many of them die on the voyage due to starvation or boat sinks (Nuswanto, 2013). Muslim Rohingya registered as refugees in Indonesia in March 2015 and 150.000 of them in Malaysia (BBC Indonesia, 20I8). Although Indonesia and Malaysia shared a similar religious background with them, Muslim Rohingya could not fit in because of their different language. Also, since the citizenship of Muslim Rohingya is rejected in I982, many of them became stateless people without any verified documents. Indonesia has saved Rohingya refugees, who lived on boats (Geutanyoe, 2016) and became one of the destination countries of the Rohingya refugees. Some policies have been made by the Indonesian government to handle these refu- 
gees. Among them is the Indonesian President's policy to conduct bilateral diplomacy with the Myanmar government, through the provision of humanitarian assistance with methods of sharing of expertise, and capacity building.

In addition, the Indonesian government also brought the Rohingya issue to the Association of Southeast Asia Nations (ASEAN) and the Organization of Islam Cooperation (OIC) forums (Ardani, 20I5). However, in 20I7, there are still 959 Rohingya ethnic refugees living in Indonesia and have not received clarity on human rights and their lives (Putra, 20I7). Moreover, most recently, on April 20I8, the fishermen in Aceh rescued 79 people of Rohingya stranded (BBC Indonesia, 2018). Until now, Rohingya refugees are still unclear about their status. In 2017, there has been a Rohingya refugee explosion, which is about I million people who came out of Myanmar to go to Bangladesh. Also, because the explosion as of March 20I8 the United Nations (PBB) has stated that the Myanmar government has violated the law and the Myanmar military will be followed up legally because it has committed genocide.

All policies that have been taken by the Indonesian government indeed have impacts on the public. Thus, this study aims to examine the response of Indonesian communities towards the Government policies related to the case of Rohingya refugees. This research is expected to become a reference and evaluation for the Indonesian government to recognize the impact of the policies that have been taken and to face if other refugees are coming to Indonesia.

\section{METHODOLOGY}

This research used a qualitative descriptive study method of analysis, which is the way to describe and illustrate the phenomenon based on the observation data. In this research, the authors describe the Rohingya issue from the policies carried out by the Indonesians government related to Rohingya ethnic refugees. The method of data collection is done using literature study by utilizing secondary data such as books, research results, journals, reports, newspapers, internet articles, and other sources relevant to this material. All of the information and data are then analyzed in-depth, one by one, and adjusted to relevant facts.

\section{THE ROOT OF DISCRIMINATIONS TOWARDS ROHINGYA}

Identifying the socio-historical roots of the problem becomes very important in understanding the Rohingya communal conflicts before learning it further. The conflict that occurred in Myanmar began in the Second World War where the Rohingya ethnic groups remained loyal to the British (Human Right Watch, 2013), while other communities, including the Rakhine ethnic, sided with the Japanese colonial, and thus the conflict between the two emerged. Furthermore, the conflict between the two increasingly heated up until finally, the Myanmar government imposed the 1982 Citizenship Law, which stated that the ethnicity recognized by the Myanmar government was an ethnic group that had long been in Myanmar before the British colonial occupation in 1824 , and there were 135 ethnicities, not including the Rohingya (Revolusi, 2013). The unfair treatment started to be felt by the Rohingya ethnic group.

Rohingya Muslim' status in Myanmar was debatable since they were entering South Arakan region in the early $2 \mathrm{O}^{\text {th }}$ century. During World War II, Rohingya took their side with the British army, while the Myanmar majority supported Japan, as they promised Myanmar their independence. From this point, the position was clear for both Rohingya and Myanmar. Sadly, in I942, Rohingya tried to destroy Arakan villages and killed around 20,000 Arakanese. Then, around 5,000 Muslims in the Minbya and Mrauk-U were killed, in return of Rohingya's act (Tha, 2008: Rafi, 20I7). In the meantime, Japan also committed serious violence towards Rohingya, such as rape, torture, and murder. These acts of violence were the main reason for 22,000 Muslims Rohingya's exodus, together with the Burmese Indian, Anglo Burmese, and British to Bengal. In response to Japan's loss in World War Il, the British army wanted to clean Burma from Japan's influence and made Volunteer Forces (V-Forces) with Rohingya. Then V-Forces with Rohingya engaged campaign against Arakanese instead to fight the rest of Japan, and they 
destroyed Buddhist monasteries, pagodas, and houses in Northen Arakan (Bayly, 2005; Irwin, I945).

The movement and the demand to create different nations were getting stronger. The Muslim leaders of Arakan asked Pakistani President, Muhammad Ali Jinnah, to claim Mayu region as the part of Pakistan, but he denied and turned down the proposal. In I947, some Muslims leader united and created Muhajeed Party. This group named themselves as Rohingya (Singh, 2007). In 1978, a number of monks protested the government, and they argued that Rohingyas was the main problem of demographic shifting in the region (Aung, I988). As a result, millions of Rohingya were forced to flee to Bangladesh as a part of Operation King Dragon (Rafi, 20I7). By the negotiations, then, Myanmar agreed to repatriate 200,000 of Rohingyas. However, the discriminations after they re-entered Myanmar were not anticipated by them.

Some sources said that the unfair treatments experienced by the Rohingya groups and that triggered the beginning of this conflict include cases of rape, discrimination against minorities, and problems of ethnic entities. However, the root of the conflict is inter-ethnic social jealousy, in which the majority of the Rakhine ethnic group was against the ethnic Rohingya minorities, who over the past few decades have owned the resources. Apparently, for the Rakhine ethnic, the existence of Rohingya ethnic means reducing their rights to the land and the economy, especially in the Arakan region, Rakhine. This condition is exacerbated, where the Myanmar government does not recognize the status of Rohingya ethnicity and does not help the Rohingya groups. They hoped that the government could end the conflict, but instead they expelled them. Therefore, the persecution and massacre of Rohingya ethnic groups continue to this day (Asriayani, 2013).

The Myanmar government began to be seen as being repressive and anarchic towards the Rohingya through the military junta policy "Operation Naga Min in I978", large-scale military operation in the Arakan region. This operation is intended as a pretext to eradicate the group that was accused of separatist efforts in the northern region of Arakan, Rohingya ethnic group. Many Rohingya people suffered from torture, arbitrary arrest, and mass murder. They are accused of being affiliated with rebels who want to establish an Islamic state in the Mayu area, northern Rakhine bordering with Bangladesh. Many Rohingyas fled to Bangladesh to seek refuge from the military operation. Since that incident, Rohingya citizens have been considered illegal immigrants (Saragih, 20I7). The Rohingya conflict that has happened for a long time and continues to happen until now has become one of the most heart-breaking human tragedies in this century. The current condition that occurs is that they are without identity or state recognition and must evacuate to seek political asylum.

There are several discriminations faced by the Rohingya since General Ne Win's reign in 1978 until now. According to Yuniarto (2005), the discriminations can be divided into two main powers: the discrimination through the policy practices of the junta military by General $\mathrm{Ne}$ Win and the Burma Military. In the reign of General Ne Win, the discrimination was about the denial of citizenship, the restrictions on freedom of movement, the obstacles of family system development, and the forced labor for Buddhist resettlement or model villages. Then, the discriminations continued by the Burma military, including forced labor, arbitrary taxation, economically controlled through a monopoly system, and the regulation of paddy procurement. The discrimination has become the main reason why Rohingya Muslims tried to flee to other regions, in addition to their basic rights as the minority that are almost disappeared under the circumstances.

The most recent condition, on August 25, 20I7, there was a massacre of the Rohingya group that forced around 671,5000 Rohingyas to cross the Cox's Bazar border and fled to Bangladesh, thus became a humanitarian emergency crisis. The refugees were in a deplorable condition where they did not have food or other basic necessities, and they solely relied on aid. Many of them died due to these harsh conditions. US State Department reports have published the 
latest report on the violence against Rohingya in Rakhine in August 2017, stating that the massacre of Rohingya was carried out in a coordinated and planned manner (Dikarma \& Aini, 2018). Until now, by March 2018, the RRRC Family Counting Exercise, supported by UNHCR, has counted 836,210 refugees in total in camps and settlements - including the arrivals both before and after August 2017 (ISCG, 20I8). Bangladesh authorities claim that I,092,136 Rohingya refugees are now sheltering in their country and seven-hundred-and-ninety hectares of land (2000 acres) have been provided for the camp which becomes the world's biggest refugee camps to house all the 800,000-plus Rohingya refugees (ICSG, 2018; The Guardian News, 20I7). Only about 500,000-600,000 Rohingya Muslims now remain in Myanmar, and their situation is very vulnerable.

Based on all these crime incidents, on Monday 27 August 2018 in Geneva, The UN Human Rights Council presented the results of the Fact-Finding Team's investigation into Myanmar under the auspices of the Office of the United Nations High Commissioner for Human Rights (OHCHR). The investigation lasted for approximately one year by interviewing key persons and witnesses, researching, and analyzing various data found. The report stated that high-ranking officers and military commanders and leaders of Myanmar's civil administration carried out genocide and other crimes against humanity in the crackdown on Rohingya Muslim minorities (Hasan, 20I8). The results are expected to be a bright spot for the Rohingya ethnic group to be able to return to their home country.

\section{A. Limitation and Definition of Refugees}

Regulations concerning displacement in international law are regulated in the Geneva Conventions of I95I and are supplemented by the New York Protocol in I967 (after this referred to as the 1951 Convention and 1967 Protocol). Three main things as the content of the convention include: First, it regards the basic understanding of refugees. The basic definition of Refugees defined in the I95I Convention and the I967 Protocol is crucial because it is necessary to determine a person's refugee status (including refugees or not). This decision is determined by the country where the person is located and if it cooperates with UNHCR, the UN organization that deals with refugee problems. Second, it determines the legal status of refugees and the rights and obligations of refugees in refugee camps. Third, it determines the implementation (implementation) of the agreement, especially concerning administration and diplomatic relations.

According to the I95I Convention, someone is determined to be a refugee if the person:

I) is outside of his/her country of nationality.

2) has a well-founded fear of persecution.

3) for reasons of race, religion, nationality, membership of a particular social group, political opinion.

4) is unable or, owing to such fear, is unwilling to avail himself of the protection of his country.

In the 195I Convention, the definition of refugees as "someone who is due to a reasonable fear of persecution, which is caused by reasons of race, religion, nationality, membership of a particular social group and membership of a particular political party, are outside their nationality and do not want protection from the country". From this definition, what needs to be underlined is the compulsion of a person/group of people to break ties with their home country, because of a fear of being persecuted (persecution). This definition distinguishes refugees from other types of migrants. The protection of refugees is primarily the responsibility of each country. This situation is explicitly contained in the 195I Convention and 1967 Protocol on Refugee Rights.

Indonesia was not included in the party that signed the 1951 Convention and 1967 Protocol so that in this context, there was no obligation for Indonesia to accept refugees. However, Indonesia's attitude to receiving refugees proves that Indonesia has upheld the value of humanity. Indirectly, Indonesia has applied the principle of non-refoulment, namely the rights of refugees of not forcibly repatriated. It is just a matter of humanity so that even 
though a country has not ratified the I95I Convention and I967 Protocol, all countries, including Indonesia must apply this principle as part of the international customary law.

\section{B. Indonesia Constitutional Immigration Policy}

\section{Indonesia Foreign Policy}

The Rohingya conflict has caused around $43 \%$ of the population to become refugees, and more than $87 \%$ of them lack basic needs such as clothing, food, shelter, health services, and access to education for the children. This conflict has become a humanitarian tragedy, which has implications for the ASEAN Region.

Regarding constitutional regulations, Indonesia did not ratify the I95I Vienna Conference and its protocol in 1967 . Hence, Indonesia has no obligation and commitment to taking action towards refugees or asylum seekers. However, the Indonesian government has done several things in following the regulations that entered Indonesia, namely the Constitution of Indonesia Number 5/1998 concerning the ratification of the Convention against torture or cruel, inhuman, or degrading punishment. Article 3 of that constitution states that the government must not refuse, return, or extradite a person who comes to the country with a severe and robust reason because of the target of punishment. This regulation becomes the reference and basis for Indonesian people to act and accept the Rohingya refugees. Therefore, Government regulation number 3I of 2013 regulates that the detention of refugees (illegal immigrants) in Indonesia lasts for up to Io years.

The Indonesian government responded formally to Rohingya refugees and the reality of it, through the Indonesian Ministry of Foreign Affairs. The Indonesian government swiftly took strategic steps to initiate a meeting with the Malaysian and Thailand foreign ministers to temporarily accommodate and provide the best assistance to Rohingya ethnic refugees. Furthermore, from the meeting, the Indonesian government actively invited other countries in the ASEAN region to join in providing comprehensive humanitarian protection. The Ministry of Foreign Affairs of Indonesia became the pioneer for the initiative carried out by ASEAN. The Association of Members of the Assembly in ASEAN for Human Rights (APHR) gave recommendations to the UN Security Council to bring the case to the International Criminal Court (Ware, 20I8). The Indonesian government also explicitly asked all parties to immediately stop the acts of violence, contribute to the restoration of security, and respect human rights. This act is intended to maintain peace, security, and stability of foreign policies in the ASEAN region.

Regarding Indonesia's participation in the Rohingya ethnic refugee diplomacy and advocacy towards the Myanmar government, the role of the Indonesian government cannot be too far, considering that in the ASEAN context there is a principle of non-intervention. This principle emphasizes the freedom of each country to regulate its internal affairs without interference from other countries. This situation is such a dilemma for ASEAN countries or organizations since they cannot enter and intervene in the problems within the Myanmar state. This principle is a dividing barrier for ASEAN countries to play an active role in helping resolve the Rohingya ethnic refugee problem.

Indonesian people (NGOs, media, volunteers, activists, and others) also show their concern for Rohingya ethnic refugees. Various solidarity activities were carried out to help them. For example, seminars and fundraisings as a protest action have been held as a form of solidarity with the Rohingya ethnic group. Even though it was a bit late in doing the aid, considering this issue had been going on for a long time, the assistance and all the actions taken by the Indonesian people were quite meaningful and were able to ease their burden, such as sending foods, clothes, and assistants, and building a hospital for them (Hasan, 20I7).

\section{Indonesian Law and Regulation}

The Myanmar government, which is supposed to take full responsibility for the Rohingya ethnic group, has instead acted oppositely, by allowing the Rohingyas to be stateless citizens. It results in continuing waves of escape and displacement of Rohingya ethnic groups that 
spread to various countries (Krustiyati, 20I2). For humanitarian reasons, the Indonesian government is inevitably responsible for asylum seekers (or later those who are assigned refugee status). Therefore, by temporarily accommodating them, the Indonesian government is ready with all the consequences of receiving refugees.

Indonesian authority is nothing more than a temporary host country, as well as helping return refugees to get to the destination country (country of origin) or third country offered (repeated). In the context of the handling of Rohingya ethnic refugees, the Indonesian government cooperates with 2 (two) international institutions that deal with refugee issues, UNHCR and IOM. UNHCR (United Nations High Commissioner for Refugees) is the United Nations High Commission (United Nations) on Refugees. UNHCR is an international institution that is mandated to provide international protection and a permanent solution for refugees by helping governments, other actors or related organizations to provide facilities for repatriation or placement of refugees (Article I Statute of the Office of the United Nations High Commissioner for Refugees I951.) While IOM is responsible for providing daily needs, including food, health, and clothing.

The attitude of the Indonesian government in accommodating refugees refers to Pancasila as the philosophy and outlook on life, and the I945 Constitution as the source and foundation of the national law. The Indonesian people uphold human dignity based on this law, as reflected in the just and civilized humanity precepts. Furthermore, the constitutional mandate states that the Indonesian people participate in creating world peace. Although Indonesia has not become a part to the I95I Convention and I967 Protocol, as a part of the international community, Indonesia is morally responsible for carrying out the general statement on $\mathrm{Hu}^{-}$ man Rights (Universal Declaration of Human Rights). Moreover, in practice, Indonesia has consistently applied the universal principle of human rights.

Looking into the detail, the underlying values and principles of the I95I Convention and I967 Protocol are also contained in several laws of Indonesia, such as in Law Number 5 of 1998 concerning the Ratification of the Convention Against Torture and Other Cruelties, and in Human or Degrading Treatment or Punishment. In this Act, it is affirmed that Indonesia as a part of the international community promotes an attitude of respect and respects and upholds the principles and objectives of the Charter of the United Nations and the Universal Declaration of Human Rights. Furthermore, Indonesia has implemented Law Number 39 of 1999 concerning Human Rights, that the State of the Republic of Indonesia recognizes and upholds human rights and fundamental human freedoms as rights, that are inherent and not separated from humans. These rights must be protected, respected, and upheld for the enhancement of human dignity, welfare, happiness, and intelligence and justice. In Article 28 of this law, it is stated that everyone has the right to seek asylum to obtain political protection from other countries. This law indicates that this Act strengthens the I95I Convention and the 1967 Protocol.

Indonesia has made policies through Presidential Regulation (Perpres) number 125 of 2016 concerning Handling Refugees from Abroad. Based on the regulation, the Indonesian government handles refugees based on International legal regulations on cooperation. It is done between the Central Government and the United Nations (UN), through the High Commissioner for Refugee Affairs in Indonesia and/or international organizations, which are international organizations on migration affairs or the humanitarian field. This regulation makes Rohingya refugees in Indonesia able to transit and no longer sway in the ocean. This situation means that the Indonesian government has primary responsibility for maintaining international peace and security. Recently, Indonesia also won a non-permanent seat in the Security Council. It is a strategic position for Indonesia to be able to participate in maintaining peace. Also, Indonesia is expected to be a voice moderator and consensus builder among the board members, based on the responsibility for diplomatic crises including the Rohingya 
human crisis in Myanmar and Bangladesh (Sheany, 20I8).

As mentioned above, in this context, the Indonesian government is working with UNHCR and IOM. The intended refugee handling regulation includes discovery, shelter, security, and immigration control. This regulation can be said to be quite comprehensive, which includes protection of the rights of refugees and asylum seekers, special attention to vulnerable people who are in an emergency situation at sea and land, and the sick, pregnant, disabled, children, and elderly. Also, the regulation provides recognition for a family union, clarity of the definition of refugees, the distribution of roles between institutions and the principle of shared responsibility, and the use of state budget for refugee protection.

As a note, a problem of refugees requires handling that follows the humanitarian principles, especially for those who are forced to leave their home countries, because of persecution. Thus, international protection is a vital need for him. The most important thing from the implementation of the regulations and laws above is not only about how refugees are handled, but also taking into account the national interests, especially the security and sovereignty of the country, and the survival of the Indonesian people without being disturbed by the existence of refugees. The Indonesian government can take lessons from the Rohingya ethnic case. Despite the existence of regulations and laws concerning the handling of refugees, Indonesia cannot just ignore the existence of international conventions on refugees. The Indonesian government needs to ratify these conventions in order to become a state party so that Indonesia's role is more effective at the international level.

\section{DISCUSSION}

Indonesia has a diversity of cultures, religions, ethnicities, races, and languages, causing its people to be vulnerable to being swayed by certain parties. The Rohingya case is a good example of this situation. The Rohingya case involves the issue of Islam and Buddhism so that some parties did propaganda on humanitarian issues and shifted the issue to the issue of religion, causing unbalance in society (Munir, 2017). This condition has resulted in many Indonesian people carrying out free actions to oppose the Myanmar government because they have oppressed their Rohingya ethnic group who is Muslims. Whereas what really happened was that many other factors such as economics and politics were more instrumental and relevant in the case of the Rohingya refugees. Therefore, the policies taken by Indonesia's government have impacts on the social, economic, and political life in this country. These impacts will be felt both by refugees and by the Indonesian people.

Since the beginning of the cold war, Indonesia has held the freedom and active foreign policy by founding and joining the Non-Alignment Movement. This foreign policy makes Indonesia become the creator of peace and neutral for every war situation. Indonesia has tried its best to help others, such as sending the peace army of Indonesia to Kongo and becoming the host for the refugees of the Vietnam War since the late of 1955. Indonesia follows the Viena Conference rules about treating refugees and asylum seekers. However, Indonesia's regulation towards Muslim Rohingya is still debatable. There are still many Muslim Rohingya who live below the standards of living and cannot fulfill their basic needs because of their citizenship status. Besides, if Indonesia gives too much attention to Muslim Rohingya, it could lead to another social problem in society.

Besides, several things have happened in response to these policies and caused problems for refugees and residents. In the act of helping Muslim Rohingya, there were some local communities appear to gather sympathy, such as The Action Group of Indonesian Moslem Student (Kesatuan Aksi Mahasiswa Muslim Indonesia) and Muhammadiyah Disaster Management Center who tried to help Muslim Rohingya in the refugee camp. These movements appeared massively in 2015 and became popular in the public discussion and on social media. Some local activists even tried to make some demonstrations in order to urge 
the government to be the leading actor in the United Nations and to stand up for Muslim Rohingya. They argued that Indonesia, as the most prominent Muslim country in the world, had to protect and assist Muslim Rohingya to bring their citizenship status back. According to Pew Research and BPS data, there are 209 million Muslims in Indonesia, which is $13,7 \%$ of the Muslim population in the world.

Many of Muslim Rohingya came to Indonesia because they were rejected by other countries, like Thailand and Malaysia. Some of them became the refugees in Indonesia because they were stranded in Indonesia in their way to Australia. Indonesia had tried their best to support the standard living for Muslim Rohingya and allowed some refugees to live at public residencies under supervision. Indonesia, with the support of UNHCR funds, built several refugees camps, like in Aceh. Indonesia also built houses and playgrounds for the children. Unfortunately, Muslim Rohingya refugees still could not get a job like others. In addition, another problem would appear if Muslim Rohingya gave birth in the refugee's camp; they could not proceed with their child's citizenship because they lacked verified citizenship document.

On the other hand, Rohingya refugees who stay in Indonesia for several years have many problems such as they have no identity, are jobless, have no health insurance, and do not have a decent living. At least there are five major problems that Muslim Rohingya have faced in many countries related to their exodus from Myanmar. (I) The citizenship problem. On the one hand, Myanmar sees Muslim Rohingya as the foreigner from Bangladesh and try to expel them from the Myanmar territory. On the other hand, Bangladesh does not acknowledge them as their citizens. It becomes a dilemma to Muslim Rohingya who became stateless and lack of citizenship status. (2) The right of having a family. Since they live in the refugee's camps, they are forced not to have a family. It would be difficult for them to create legal documents for the children. (3) The right to residency. This situation is another problem to face, and they cannot settle because they are not allowed to be in Indonesia or other countries permanently. (4) The right to get a job. Just like other problems above, they cannot get a job because they do not have verified documents of citizenship, even if they propose as legal foreign workers. (5) The last is the right to the standard health. UNHCR and the governments where the refugees live in have provided a standard camp. But just like other camps, the sanitation quality and the distribution of food become a problem when the camps are fully occupied with refugees.

Indonesian society also faces several problems dealing with Rohingya refugees, such as the fulfillment of the rights of refugees and their jobs. Besides, there have been many intermarriages between refugees and people in the surrounding community. Unfortunately, these marriages are not recorded because the civil law does not recognize mixed marriages with refugees. Many Indonesians are still carrying out various kinds of humanitarian actions, to help Rohingya refugees to be accepted again by the Myanmar state. Actions taken include being volunteers, establishing organizations, and joining several social Non-Governmental Organizations (NGOs).

One of the social actions is the Alliance of II Humanitarian Agencies in Indonesia, in the form of the Indonesian Humanitarian Alliance for Myanmar (AKIM). It consists of various NGOs, such as Muhammadiyah Disaster Management Center, Disaster Management and Climate Change Institutions - Nahdlatul Ulama, PKPU Human Initiative, Dompet Dhuafa, Rumah Zakat, Dompet Peduli- Daarut Tauhiid, LAZIS Wahdah, Laznas Infaq Management Institute (LMI), Aksi Cepat Tanggap, Lazis Da'wah Islamiyah Indonesia, Social Trust Fund - UIN Jakarta in collaboration with the Indonesian government (Ministry of Foreign Affairs) and all elements of Indonesian society. They are in this together to support Indonesian foreign policy to provide humanitarian services for the Rohingya refugees in Indonesia, even though Indonesia has not ratified the I95I Convention on refugees (Tauhid, 2017).

Another support also comes from Nahdlatul Ulama (NU), as the largest Islamic organization in Indonesia. NU, through the 
Executive Board of Nadhlatul Ulama (PBNU), along with several other interfaith leaders, has expressed their attitude regarding the Rohingya ethnic conflict, which explicitly called on the Indonesian government and the international community to provide humanitarian assistance, and immediately take diplomatic steps to convince the Myanmar government to stop the humanity tragedy.

After witnessing and observing the repression and human tragedy that occurred in Rakhine State, Rohingya, Myanmar, the Executive Board of the Nahdlatul Ulama (PBNU), the Indonesian Bishops' Conference (KWI), the Indonesian Church Fellowship (PGI), Indonesian Buddhist Representatives (Walubi/ NSI), Majelis High Confucianism in Indonesia (Matakin), Parisada Hindu Dharma Indonesia (PHDI) affirms:

I) Condemn all forms of violence. The act of violence is an act that injures humanity. Whatever the reason, this is not justified by any religion and belief.

2) Appreciate and fully support the steps of the Government, in this case, President Jokowi and also Minister of Foreign Affairs Retno Marsudi in order to seek solutions to overcome the humanitarian tragedies that have occurred. This step is a concrete and swift step in responding to the ongoing tragedy.

3) Urge all international elements, the United Nations, and ASEAN to be more proactive in seeking steps and solutions in resolving the ongoing humanitarian tragedy.

4) To invite all elements not to be provoked by parties acting on behalf of conflicts that occur by dragging certain religions and beliefs. What happened in the Rohingya was the tragedy of humanity. We must put it in the eyes of humanity without ever being insulated and compartmentalized by certain beliefs. What happened in the Rohingya is more complex than just a simplification of the issue of religion. There are struggles over resources, and there are also political battles. So, the most appropriate thing is to sit down in the Rohingya as a human tragedy.

5) Calls on all religious people to actively participate in raising donations and humanitarian assistance to victims of the humanitarian tragedy in the Rohingya. The most prudent and real step needed by victims now is assistance in the form of food, health facilities, and also educational facilities (Rahayu, 20I7).

In this context, the attitude is shown by the Indonesian Humanitarian Alliance for Myanmar (AKIM) or Nadhlatul Ulama (NU) along with other religious organizations, is a form of soft-diplomacy. In addition, Indonesian society and organizations already worked hard in their capacity, invited and especially urged regional and international stakeholders to find a peaceful solution so that the rights of Rohingya ethnic citizenship can be immediately restored.

Until now, the Rohingya refugee's problem has not gotten a bright spot because it is still spreading in many places, including Indonesia. Even in Bangladesh, the number of Rohingya refugees has reached I6o million people, and the state of Myanmar is still delaying and postponing their repatriation time (Mariani \& Aini, 20I8). Indonesian Foreign Affairs Minister, Retno Marsudi, revealed that one concrete step that could be done to help the Rohingya issue was to prepare an environment that supports refugees so that they can return to Myanmar (Alamsyah, 20I8). Countries in the world which are facilitated by the United Nations also continue to hold meetings and coordination to determine steps that can be taken to overcome the problem or issue of Rohingya.

\section{CONCLUSION}

Rohingya refugees have seized the world's public attention. Even more after 2017, a massive influx of refugees has become a humanitarian crime in the world. This paper has examined and described the impacts, both physical and spiritual, that the refugees have experienced while in Indonesian camps and what has been done by the Indonesian government to overcome them. Based on the results of the 
study, it is found that there needs to be a more explicit regulation, such as the regulation for the Government which allows them to accept the refugees, the mechanisms that could be carried by the Government from the first aid, as well as the need for clear rules regarding their needs and obligations. All of these regulations are needed to regulate the entry of refugees so that the local people will not be disturbed and there will be security between both the countries of destination and origin. In the future, research related to refugees in Asia or other countries in the world can continue to be conducted, so that all countries know their obligation and rights as the host or recipient of refugees. Therefore, this kind of crime, such as a case of violation of rights and the tragedy of humanity, will not happen again in the future.

\section{REFERENCES}

Alamsyah, I. E. (2018, September 25). Krisis Rohingnya Masih Mengemuka di Sidang Majelis Umum PBB. Retrieved from www.republika. co.id: https://www.republika.co.id/berita/ internasional/asia/ı/o9/25/pfmcqo349krisis-rohingya-masih-mengemuka-disidang-majelis-umum-pbb

Alunaza, H., \& Juani, M. K. (20I7). Kebijakan Pemerintah Indonesia melalui Sekuritisasi Migrasi Pengungsi Rohingnya di Aceh Tahun 20I2-20I5. Indonesia Perspective, 2(I), I-I7.

Ardani, F. A. (2015). Kebijakan Indonesia dalam Membantu Penyelesaian Konflik Antara Etnis Rohingya dan Etnis Rakhine di Myanmar (Studi karakter Kepribadian Susilo Bambang Yidhoyono). Journal of International Relations, I(2), 22-28.

Aung, T. (1988). Civil Insurgency in Burma. Yangon: Ministry of Information.

Azad, A., \& Jasmin, F. (2013, October-December). Durable Solutions to The Protracted Refugee Situation: The Case of Rohingyas In Bangladesh. Journal of Indian Research, I(4), 25-35.

Bayly, C. \&. (2005). Forgotten Armies: The Fall of British Asia, I94I-I945. London: Harvard University Press.

BBC Indonesia. (2018, April 20). Lagi, Nelayan Aceh Selamatkan 79 Pengungsi Rohingya. Retrieved from www.bbc.com: https://www.bbc.com/ indonesia/indonesia-43837197
BBC Indonesia. (20I8). News. Retrieved from www. bbc.com: https://www.bbc.com/indonesia/ dunia-42702442

Dikarma, K., \& Aini, N. (2018, September 25). AS Kucurkan Dana Bantuan Untuk Pengungsi Rohingya. Retrieved from www.republika.co.id: https:// www.republika.co.id/berita/internasional/ amerika/ı8/o9/25/pflwoy382-as-kucurkandana-bantuan-untuk-pengungsi-rohingya

Ekeh, Chizom, \& Smith, M. (2007). Minorities in Burma. Retrieved from Minority Rights Group International 30: http://www.refworld.org/ pdfid/47298f632.pdf.

Geutanyoe, T. Y. (2016). Hidup Dalam Penantian Setahun Pengungsi Rohingnya di Aceh. Aceh: The Geutanyoe Foundation.

Gill, F. S. (2015). Human Rights and Statelessness: The Case Study of the Rohingya in Myanmar. LAP LAMBERT Academic Publishing.

Hasan, R. A. (20I7, November 20). Indonesia Memulai Pembangunan Rumah Sakit di "Kampung" Rohingya. Retrieved October I0, 2018, from Liputan6: https://www.liputan6.com/global/ read/3168579/indonesia-memulai-pembangunan-rumah-sakit-di-kampung-rohingya

Hasan, R. A. (2018, August 30). Tolak Laporan PBB, Myanmar bantah melakukan Genosida terhadap Muslim Rohingya. Retrieved from Liputan6: https://www.liputan6.com/global/ read/3632159/tolak-laporan-pbb-myanmarbantah-melakukan-genosida-terhadapmuslim-rohingya

International, A. (2012). Myanmar: Abuse againts Rohingnya erode human rights progress. Amnesty International.

Irwin, A. (1945). Burmese Outpost (Memoirs of a British Officer who fought in Arakan with the Arakanese $V$ forces during the Second World War) . London: Collins.

ISCG, Inter Sector Coordination Group. (20I8). Situation Report: Rohingya Refugee Crisis. Cox's Bazar: March.

Kiragu, E., Rosi, A., \& Morris, T. (20II). State of denial: A review of UNHCR's response to the [rotracted situation of stateless Rohingya refugees in Bangladesh. Switzerland: Policy Development and Evaluation Service United Nations High Commissioner for Refugees. Retrieved from UNHCR: http://www.unhcr.org/4ee754cig. pdf

Kiragu, E., Rosi, A., \& Morris, T. (20II). State of denial: A review of UNHCR's response to the [rotracted situation of stateless Rohingya refugees in 
Bangladesh. Retrieved from UNHCR: http:// www.unhcr.org/4ee754ci9.pdf

Krustiyati, A. (2012, November). Kebijakan Penanganan Pengungsi di Indonesia: Kajian dari Konvensi Pengungsi Tahun I95I dan Protokol I967. Law Review, XII(2), I7I-I92.

Mariani, \& Aini, N. (2018, September 26). Bangladesh Tuding Myanmar Sengaja Tunda Pemulangan Rohingnya. Retrieved from www.republika. co.id: https://www.republika.co.id/berita/ internasional/asia/ı8/o9/26/pfnocz382bangladesh-tuding-myanmar-sengaja-tundapemulangan-rohingya

Munir, S. (2017, September I4). Indonesia Diminta Waspada Dampak Konflik Kemanusiaan Myanmar. Retrieved from Sindonews.com: https:// nasional.sindonews.com/read/I239630/I5/ indonesia-diminta-waspada-dampak-konflikkemanusiaan-myanmar-I505377635

Nuswantoro, B. S. (2015). Sikap Negara SEAN Terhadap Pengungsi Rohingnya Studi Komparatif: Kabijakan Indonesia dan Thailand. Yogyakarta: Fakultas Ilmu Sosial dan Ilmu Politik Universitas Gadjah Mada .

Pratama, A. Y. (20I4). Status Pengungsi Rohingnya, Myanmar Ditinjau Dari Hukum Internasional. Padang: Fakultas Hukum Universitas Bung Hatta.

Purwanto, A. (20I7, June 3). Menelisik Akar Persoalan Rohingya. Retrieved from www.kompas.com: http://print.kompas.com/baca/2015/o6/03/ Menelisik-Akar-Persoalan-Rohingnya

Rafi, A. (20I7). How Does Organizational Evolve? A Study on Rohingya Solidarity Organization (Undergraduate Thesis. Dakha, Bangladesh: University of Dakha.

Rahayu, C. M. (2017, September 22). PBNU dan Tokoh Lintas Agama Nyatakan Sikap Untuk Rohingya. Retrieved from Detik News: https://news.detik.com/berita/d-3654202/ pbnu-dan-tokoh-lintas-agama-nyatakansikap-untuk-rohingya

Rahman, K. A. (2015). Ethno-Political Conflict: The Rohingya Vulnerability in Myanmar. International Journal of Humanities and Social Studies, 2(I), 288-295.

reliefweb. (20I8, March 30). ISCG Situation Report: Rohingya Refugee Crisis, Cox's Bazar. Retrieved from ReliefWEB: https://reliefweb.int/report/ bangladesh/iscg-situation-report-rohingyarefugee-crisis-cox-s-bazar-25-march-2018

Revolusi, A. (2013). Faktor-Faktor Penyebab Konflik Etnis Rakhine dan Rohingya di Myanmar.
Artikel Ilmiah Hasil Penelitian Mahasiswa UNEJ, 2.

Riley, D., Varner, A., Ventevogel, P., \& Hasan, T. M. (20I7). Daily stressors, trauma exposure, and mental health among stateless Rohingya refugees in Bangladesh. Transcultural Psychiatry, 54(3), 304-331.

Saragih, H. M. (20I7). Indonesia dan Responsibility To Protect Etnis Muslim Rohingnya Myanmar. Jurnal Kajian Keislaman dan Kemasyarakatan.

Sawal, I. A. (20I7). Implikasi Kemanusiaan Rohingnya di Myanmar Terhadao Negara-Negara Asean. Makassar: Fakultas Ilmu Sosial dan Ilmu Politik Universitas Hasanuddin.

Sheany. (2018, June o9). Indonesia Wins UN Security Council Seat. Retrieved from Jakarta Globe: http://jakartaglobe.id/news/indonesia-winsun-security-council-seat/

Singh, B. (2007). The Talibanization of Southeast Asia: Losing the War on Terror to Islamist Extremist. New York: Praeger.

Tampubolon, J. S., Rahman, A., \& Bariah, C. (20I3). Perlindungan dan Penegakan HAM di ASEAN Terhadap Manusia Perahu Rohingnya dalam Status Sebagai Pengungsi Menurut Hukum Internasional. Sumatra Journal of International Law.

Tauhid, D. (2017, September 6). Release Resmi Aliansi Kemanusiaan Indonesia untuk Myanmar (AKIM). Retrieved from Dompet Peduli Ummat, Daarut Tauhid: https:// dpu-daaruttauhiid.org/web/news/detail/ Release-Resmi-Aliansi-Kemanusiaan-Indonesia-untuk-Myanmar-AKIM

Tha, S. K. (2008, December 28). Background of Rohingya Problem. Retrieved from SCRIBD: https:// www.scribd.com/document/I2964670/ Background-of-Rohingya-Problem

The Guardian. (20I7, June 6). Bangladesh to build one of the world's largest refugee camps for 800,000 Rohingya. Retrieved from The Guardian: https://www.theguardian.com/world/20I7/ oct/o6/bangladesh-build-worlds-largestrefugee-camps-80oooo-rohingya

Ula, S. (20I7). Peran Aktor Non-Negara dalam Hubungan Internasional: Studi Kasus Human Rights Watch dalam Krisis Kemanusiaan di Myanmar. Jurnal of International Relations, 3(3), I9-28.

UNHCR, I. (2018). Pengungsi. Retrieved from UNHCR Indonesia: http://www.unhcr.org/ id/pengungsi 
Untoro, Y., Idris, M., \& Hardiwinoto, S. (20I6). Peran ASEAN dalam Penanganan Pengungsi Pencari Suaka yang Ada di Indonesia (Studi Kasus Pengungsi Rohingnya di Aceh). Diponegoro Law Journal, 5(3), I-I6.

VOA, I. (20I2, June 3). UNHCR: Jumlah Pengungsi di Dunia akan Terus Bertambah. Retrieved from VOA Indonesia: https://www.voaindonesia. com/a/unhcr-jumlah-pengungsi-di-duniaakan-terus-bertambah-/II46504.html

Ware, A. (2018, August 3I). Explainer: Why the uN has found Myanmar military committed genocide against the Rohingya. Retrieved from The Conversation: https://theconversation.com/ explainer-why-the-un-has-found-myanmarsmilitary-committed-genocide-against-therohingya-I0225I
Watch, H. R. (2013). "All You Can Do Is Pray": Crimes Against Humanity and Ethnic Rohingya Muslims in Burma's Arakan State. New York: Human Right Watch.

Wibisono, A. N. (2013, Agustus 20). Rohingnya dan Krisis Kemanusiaan di Myanmar. Retrieved 2018, from www.anwibisono.com: http:// www.anwibisono.com/20I3/o8/aseanrohingnya-dan-krisis-kemanusiaan.html

Yuniarto, P. (2005). Multiculturalism, Separatism, and Nation State Building in Burma. Jakarta: Pusat Penelitian Sumberdaya Regional (PSDR-LIPI). 
